\title{
Cutting and regeneration of roots and seedlings from seeds of Eugenia candolleana DC. at different maturity stages ${ }^{1}$
}

\author{
Camila Rivero Alonso ${ }^{2}$, Lilian Maria Asperti², Marina Crestana Guardia² ${ }^{2}$, \\ Claudio José Barbedo ${ }^{2 *}$ iD
}

\begin{abstract}
The potential to generate new roots and even whole plants even after the removal of most of their reserves is a typical characteristic of monoembryonic seeds of species of the genus Eugenia. Previous studies have shown that seeds of Eugenia can produce seedlings even with only $1 / 4$ of their mass, including seeds at the initial stages of maturity or seeds already in germination. This could be an important ecologically strategy for ensuring propagation of Eugenia species since they would be able to develop serial seedlings from the same seed, depending on environmental conditions, but this has not yet been evaluated. In this study, seeds of $E$. candolleana at four maturity stages were cut longitudinally or transversally, and they maintained high germination percentages and production of normal seedlings. In a second experiment, the first and second seedlings that developed were removed and regeneration capacity was also evaluated. The results showed that it was possible to obtain more than one normal seedling from each seed. They also showed that even after root and shoot removal, regeneration of new roots and seedlings occurred. These characteristics could be understood as evolutionary strategies to ensure natural propagation of this species in an unsuitable environment.
\end{abstract}

Index terms: Myrtaceae, recalcitrant seeds, propagation.

\section{Fracionamento e regeneração de raízes e plântulas em sementes de Eugenia candolleana DC. em diferentes estádios de maturação}

\begin{abstract}
RESUMO - O potencial para gerar novas raízes e até plantas inteiras, mesmo após a remoção de grande parte de suas reservas, é uma característica típica das sementes monoembriônicas de espécies do gênero Eugenia. Trabalhos anteriores mostraram que sementes de Eugenia podem produzir plântulas mesmo quando apenas 1/4 de sua massa está presente, inclusive para sementes em estádios iniciais de maturação ou já em processo de germinação. Ecologicamente, esta poderia ser uma estratégia importante para garantir a propagação das espécies de Eugenia, uma vez que elas seriam capazes de produzir plântulas de forma seriada, a partir da mesma semente, dependendo das condições ambientais, mas isso ainda não foi estudado. Neste trabalho, sementes de E. candolleana de quatro fases de maturação foram cortadas longitudinal ou transversalmente e mantiveram altos percentuais de germinação e produção de plântulas normais. Em um segundo experimento, a primeira e segunda plântulas desenvolvidas foram removidas e a capacidade de regeneração também foi avaliada. Os resultados mostraram que foi possível obter mais de uma plântula de cada semente. Também evidenciaram que, mesmo após a remoção das raízes e das partes aéreas, foi possível a regeneração de novas raízes e plântulas. Essas características poderiam ser entendidas como estratégias evolutivas para garantir a propagação natural dessa espécie em ambiente inadequado.
\end{abstract}

Termos para indexação: Myrtaceae, propagação, semente recalcitrante.

\section{Introduction}

Eugenia candolleana DC., popularly known as rainforest plum or "ameixa-da-mata", is 3-6 $\mathrm{m}$ in height and has an open canopy and white flowers. It flowers during the months of December - January (Lorenzi, 2009). In peoples' home remedies, the infusion of its leaves has been used to combat pain and fever because it is known that the

${ }^{1}$ Submitted on $05 / 23 / 2018$. Accepted for publication on 01/13/2019.

${ }^{2}$ Instituto de Botânica, Núcleo de Pesquisa em Sementes, Caixa Postal 68041, 04301012 - São Paulo, SP, Brasil.

*Corresponding author < cjbarbedo@yahoo.com.br $>$ 
essential oil of $E$. candolleana leaves has anti-inflammatory properties (Guimarães et al., 2009; Nakamura et al., 2010; Lenardão et al., 2016). The essential oil of this species, rich in sesqueterpenes, also showed larvacide activity against Aedis aegypti, representing a natural alternative for eradication of the mosquito that transmits yellow fever and dengue (Neves et al., 2017). Dark fruit, like that of E. candolleana, together with red fruit, are preferred by birds, making such species beneficial for ecological restoration programs. It is widely distributed, from Bahia to the Zona da Mata region of Minas Gerais in the Restinga of Atlantic rain forest (Lorenzi, 2009; Gagetti et al., 2016).

Studies performed with cuttings of Eugenia spp. seeds showed that more than one plant can be obtained from one seed (Silva et al., 2005; Amador and Barbedo, 2011; Teixeira and Barbedo, 2012; Prataviera et al., 2015; Calvi et al., 2016). It was also found that dependence on cuttings for development of these tissues indicates that injuries in seeds may initiate some process of inducing formation of new roots and seedlings, or they may block the autoinhibition of these formations in seeds (Delgado and Barbedo, 2011; Amador and Barbedo, 2015).

The seed cuttings made in a transversal section of $E$. stipitata showed good regenerative potential; in the halves that remained with the hypocotyl-radicle axis, $89 \%$ germination was achieved and, moreover, $20 \%$ in their opposite halves, which would total 109\% germination (Anjos and Ferraz, 1999). Other examples are of seeds of E. uniflora, E. brasiliensis, and $E$. involucrata, with germination also exceeding $100 \%$, ranging from $114 \%$ to $166 \%$ (Silva et al., 2005). Such data suggest that this is a feature that may be extended to the entire genus. The regenerative capacity in seeds after cutting was also observed in two genera of the family Clusiaceae, Garcinia and Allanblackia (Malik et al., 2005; Joshi et al., 2006; Asomaning et al., 2011; Ofori et al., 2015), which also have recalcitrant seeds (Nascimento et al., 2001).

It is noteworthy that in Eugenia, when seeds are not subjected to cutting, germination is never greater than $100 \%$. The formation of a second root in each fraction of these seeds when they are cut is also rare. This may indicate that regeneration of a second embryo in the same seed will only occur when it is cut and that there must be mechanisms of induction and/or inhibition arising from the cut and from germination (Silva et al., 2005; Amador and Barbedo, 2011, 2015).

For Delgado et al. (2010), regenerative capacity may have originated from a natural selection pressure influenced by predation, in which subepidermal parenchymatous cells were dedifferentiated and formed a meristematic band, thus showing rapid regeneration of the cut tissues as a form of resistance to predation. In this respect, there is likely some relationship between the cutting and the forms of predation for species of the genus under discussion.

Considering that the study of maturation of Eugenia seeds is of great relevance for understanding the behavior of the species concerning regeneration of new structures, the aim of this study was to evaluate regenerative capacity in E. candolleana seeds subjected to cutting at different stages of physiological maturity. In order to identify possible ecological advantages, regenerative capacity after elimination of the first germinations and formations of normal seedlings was also analyzed.

\section{Material and Methods}

The fruit of Eugenia candolleana DC. was collected directly from mother plants in the Botanical Gardens of São Paulo, SP $\left(23^{\circ} 38^{\prime}\right.$ S e $\left.46^{\circ} 37^{\prime} \mathrm{W}\right)$ and immediately sent to the laboratory for seed extraction. Fruit was separated into four stages of ripeness according to the color of the epicarp: stage 1 (E1), green; stage 2 (E2), green with rose-colored spots; stage 3 (E3), light red to dark red; and stage 4 (E4), dark purple color (Figure 1). The fruit was measured with a digital caliper and characterized by their greatest diameter. Seeds from the fruit in each stage of ripeness were extracted manually, removing the pulp residues with running water with the aid of a sieve for separation of the seeds from the pulp, and the excess moisture was immediately removed with filter paper. For the fruit in the first stage, the pulp was removed manually with the aid of a scalpel because it has firmer pulp. After extraction, the seeds were also measured at their greatest diameter. After that, they were placed in perforated polyethylene bags and remained in the refrigerator at $10{ }^{\circ} \mathrm{C}$ until the experiments were set up.

The initial moisture content (\%, wet basis) and the seed and fruit dry matter (in g.fruit ${ }^{-1}$ or g.seed ${ }^{-1}$ ) were determined by the air circulation laboratory oven method for 17 hours at 103 ${ }^{\circ} \mathrm{C}$ (Brasil, 2009). The water potential of the seeds and fruit was measured by the equipment WP4 (Decagon, Pullmann,

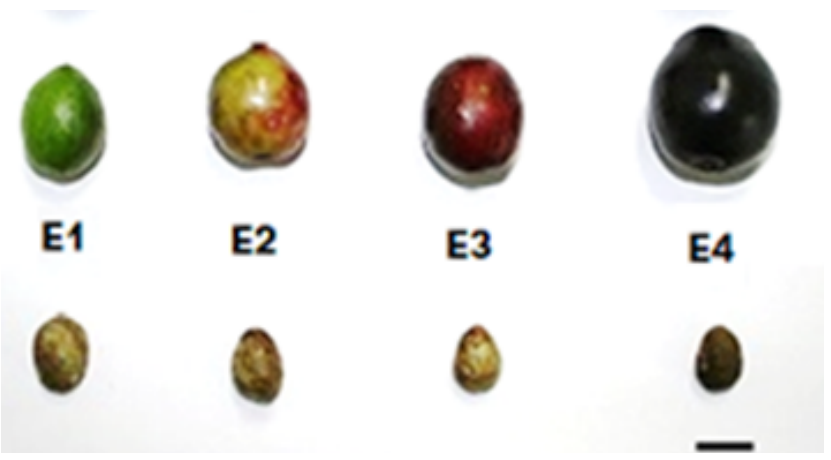

Figure 1. E. candolleana fruit, separated in four stages of ripeness (E1, E2, E3, and E4), with their respective seeds. Scale: $1 \mathrm{~cm}$. 
USA) based on the dew point temperature and expressed in megapascal (MPa). For evaluations of moisture content, dry matter, and water potential of seeds and fruit, four replications of five seeds or fruit were carried out.

Germination capacity was evaluated by the germination test, carried out in a germination chamber with continuous white light at a constant temperature of $25^{\circ} \mathrm{C}$, with four replications of 20 seeds. The seeds were placed in a transparent gerbox containing a two-centimeter layer of vermiculite as substrate and moistened with tap water up to the saturation limit. The seeds that had emergence of $0.5 \mathrm{~cm}$ of the primary root and those that produced normal seedlings were registered, i.e., seedlings with about $2 \mathrm{~cm}$ of shoot growth and a developed root system and eophiles without apparent defects, following the model adopted for other species of the same genus (Delgado and Barbedo, 2011).

A completely randomized experimental design was used, with four replications. Analysis of variance (F test, 5\%) was used on the data and the means were compared to each other by the Tukey test at $5 \%$ (Santana and Ranal, 2004).

The seeds from the last two stages of ripeness (E3 and E4) underwent four types of cutting: $\mathrm{T} 0=$ whole seeds, i.e., without cutting, constituting the control; $\mathrm{T} 1=$ seeds with a longitudinal cut in the middle in the direction of the greatest diameter, seeking to pass the cut through the hilum (placental scar); $\mathrm{T} 2=$ seeds cut in four parts radially; $\mathrm{T} 3=$ seeds cut in four parts, transversally, in the direction of smaller diameter (Figure 2). All the seed pieces were placed to germinate. Thus, a $2 \times 4$ (ages $\times$ modes of cutting) factorial arrangement was constituted in a completely randomized design with four replications of 20 seeds. Analysis of variance (F test, 5\%) was used on the data and the means were compared to each other by the Tukey test at $5 \%$ (Santana and Ranal, 2004).

For evaluation of the potential of successive germinations, seeds from the four stages of fruit ripeness were used. Three treatments were assigned: 1) natural germination (NG) whole seeds were placed to germinate in a transparent gerbox in vermiculite moistened with water without any interference, i.e., simulating natural conditions; 2) elimination of the first development (EFD) - whole seeds were placed to germinate in a gerbox, and after the seedling formed and reached $2 \mathrm{~cm}$ of shoot growth (Figure 3A), the shoot was eliminated with the aid of a scalpel very close to the seed surface (Figure 3B), removing all the plant tissue from the seedling; and 3) elimination of the second development (ESD) - the procedure adopted was the same as the EFD, however, also eliminating the seedling that regenerated after the first elimination. Evaluations were made daily in the first month, and at a threeday interval in the nine subsequent months. That way, a $4 \times$
3 (ages $\times$ eliminations) factorial arrangement was constituted in a completely randomized experimental design, with four replications of 20 seeds. Analysis of variance (F test, 5\%) was used on the results, and the means were compared to each other by the Tukey test at 5\% (Santana and Ranal, 2004).

\section{Results and Discussion}

During maturation, the moisture content of the fruit remained high (above $80 \%$, Table 1), characteristic of fleshy fruits like E. candolleana. The dry matter of this fruit, for its part, showed little difference among the first three stages, but exhibited a substantial increase from stage 3 to stage 4 . This led to increases both in the diameter and in the fresh matter of this fruit (Table 1). The seeds also maintained a high moisture content in the four stages (above $50 \%$, Table 2), characteristic of recalcitrant seeds (Barbedo et al., 2013), and

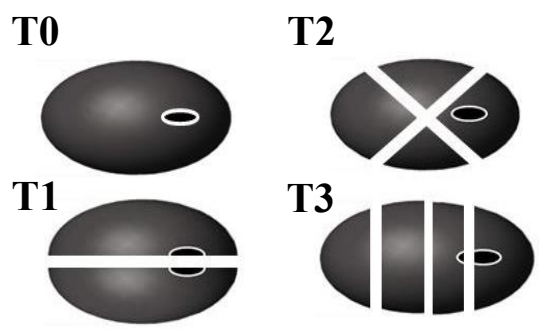

Figure 2. Schematic representation of the cuts made in $E$. candolleana seeds. T0 - control treatment, intact seeds; $\mathrm{T} 1$ - seeds cut longitudinally in the middle in the direction of greatest diameter, seeking to pass through the hilum (placental scar); T2 - seeds cut diagonally in the direction of smaller diameter; T3 - seeds cut transversally in the direction of smaller diameter.

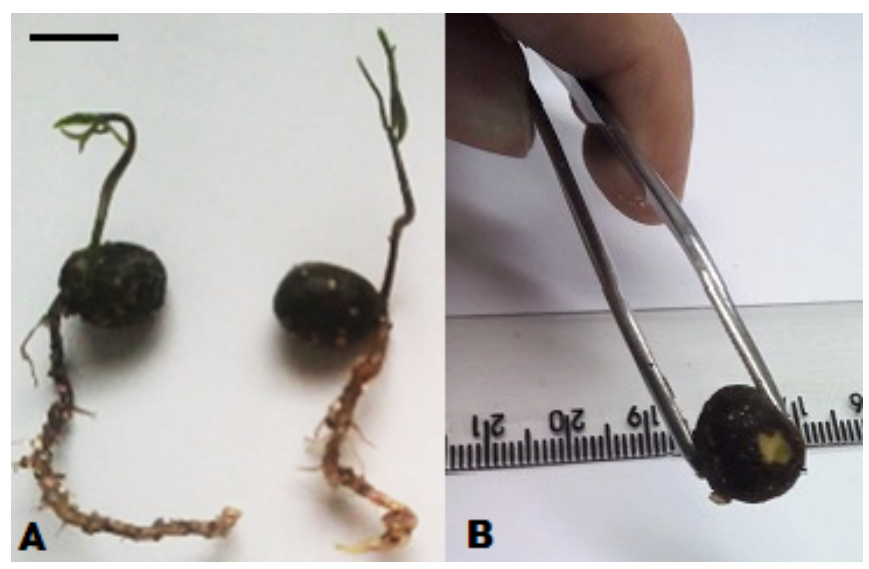

Figure 3. E. candolleana seedlings with about $2 \mathrm{~cm}$ of shoot length (A); detail of elimination made with the aid of a scalpel very near the seed surface (B). Scale: $1 \mathrm{~cm}$. 
Table 1. Diameter (DF, mm), moisture content (MC, \%), water potential (WP, MPa), fresh matter (FM, g.fruit specimen ${ }^{-1}$ ), and dry matter (DM, g.fruit specimen $\left.{ }^{-1}\right)$ of E. candolleana fruit in different stages of ripeness.

\begin{tabular}{ccccc}
\hline & \multicolumn{5}{c}{ Stages of ripeness } \\
\cline { 2 - 5 } & Stage 1 & Stage 2 & Stage 3 & Stage 4 \\
\hline DF & $19.2( \pm 0.9) \mathrm{b}^{*}$ & $21.7( \pm 0.5) \mathrm{b}$ & $21.9( \pm 0.8) \mathrm{b}$ & $25.4( \pm 0.9) \mathrm{a}$ \\
MC & $86.1( \pm 0.6) \mathrm{ab}$ & $88.5( \pm 0.2) \mathrm{a}$ & $89.6( \pm 0.3) \mathrm{a}$ & $80.5( \pm 1.8) \mathrm{b}$ \\
WP & $-1.11( \pm 0.13) \mathrm{b}$ & $-1.18( \pm 0.15) \mathrm{b}$ & $-1.38( \pm 0.07) \mathrm{ab}$ & $-1.78( \pm 0.21) \mathrm{a}$ \\
FM & $5.239( \pm 0.315) \mathrm{c}$ & $8.776( \pm 0.837) \mathrm{bc}$ & $9.796( \pm 1.169) \mathrm{b}$ & $19.129( \pm 1.870) \mathrm{a}$ \\
DM & $0.723( \pm 0.036) \mathrm{b}$ & $1.006( \pm 0.078) \mathrm{b}$ & $1.020( \pm 0.145) \mathrm{b}$ & $3.788( \pm 1.238) \mathrm{a}$ \\
\hline
\end{tabular}

*Mean values followed by the same letter in the row do not differ from each other (Tukey, 5\%)

Table 2. Diameter (DS, mm), moisture content (MC, \%), water potential (WP, MPa), fresh matter (FM, g.seed $\left.{ }^{-1}\right)$, dry matter $\left(\mathrm{DM}\right.$, g.seed $\left.^{-1}\right)$, seeds that produced a primary $\operatorname{root}(\mathrm{PR})$, and normal seedlings (NS) of E. candolleana seeds according to the stage of fruit ripeness.

\begin{tabular}{ccccc}
\hline & \multicolumn{4}{c}{ Stages of ripeness } \\
\cline { 2 - 5 } & Stage 1 & Stage 2 & Stage 3 & Stage 4 \\
\hline DS & $12.0 \pm 0.2 \mathrm{a}^{*}$ & $11.2 \pm 0.3 \mathrm{a}$ & $12.7 \pm 0.4 \mathrm{a}$ & $11.9 \pm 0.5 \mathrm{a}$ \\
MC & $57.0 \pm 1.4 \mathrm{a}$ & $54.0 \pm 0.5 \mathrm{a}$ & $55.0 \pm 1.4 \mathrm{a}$ & $56.5 \pm 1.8 \mathrm{a}$ \\
WP & $-1.41 \pm 0.28 \mathrm{a}$ & $-1.52 \pm 0.09 \mathrm{a}$ & $-1.38 \pm 0.14 \mathrm{a}$ & $-1.86 \pm 0.29 \mathrm{a}$ \\
FM & $1.724 \pm 0.122 \mathrm{c}$ & $2.320 \pm 0.185 \mathrm{~b}$ & $2.256 \pm 0.200 \mathrm{bc}$ & $3.238 \pm 0.186 \mathrm{a}$ \\
DM & $0.736 \pm 0.047 \mathrm{c}$ & $1.064 \pm 0.079 \mathrm{~b}$ & $1.010 \pm 0.083 \mathrm{bc}$ & $1.409 \pm 0.126 \mathrm{a}$ \\
PR & $49 \pm 13 \mathrm{~b}$ & $89 \pm 14 \mathrm{a}$ & $100 \pm 0 \mathrm{a}$ & $95 \pm 4 \mathrm{a}$ \\
NS & $39 \pm 15 \mathrm{c}$ & $68 \pm 4 \mathrm{~b}$ & $95 \pm 4 \mathrm{a}$ & $88 \pm 4 \mathrm{a}$ \\
\hline
\end{tabular}

* Mean values followed by the same letter in the row do not differ from each other (Tukey, $5 \%$ )

had an increase in dry matter from stage 1 to stage 2 and from stage 3 to stage 4 . It is noteworthy that although the amount of water in the seeds did not change from stage 3 to stage 4 , the activity changed, as seen by water potential, which became more negative (Table 2). This suggests that changes occurred in the chemical composition or in the structure of the seeds between these two stages. More negative water potentials may indicate an increase in the concentration of solutes in the cell solution, such as sugars, metabolites, ions, and proteins (Taiz and Zeiger, 2004). Among the events that bring about such change in seeds is germination, which uses compounds accumulated during maturation, transforming them into smaller molecules (Kermode, 1990; Barbedo et al., 2013; Marcos-Filho, 2015), frequently increasing the number of sites for binding with water molecules.

The seeds acquired the capacity to germinate already in the first stage from fruit with an epicarp that was still green (Figure 1), in which about $50 \%$ produced a primary root and about $40 \%$ developed normal seedlings (Table 2). In stage 2 , the capacity to produce a primary root was present in nearly all the seeds, although only about $70 \%$ were able to develop seedlings. From stage 3 on, both these values neared $100 \%$. This behavior, i.e., the investment in germination of still quite immature seeds, has already been identified in other species of the genus, such as E. pyriformis (Oro et al., 2012; Lamarca et al., 2013), E. uniflora (Avila et al., 2009), and E. involucrata (Oro et al., 2012). This showed, once more, that there is no synchrony between ripening of fruit and seed maturation in Eugenia species (Lamarca et al., 2013). Even though the ripe and unripe fruit of $E$. candolleana had completely different colors, their seeds had few physiological differences.

There was no significant interaction between stages of ripeness and types of cutting (Figure 4), and the seeds of E3 were more efficient in primary root emergence when undergoing cutting. Cutting in only two parts resulted in gains in primary root emergence, but cutting in four parts resulted in decreases in these values (Figure 4). This decrease was not found in other species of Eugenia (Silva et al., 2005; Delgado et al., 2010), showing that the regenerative capacity of $E$. candolleana is not as efficient as other species of the genus. However, with longitudinal cutting in two parts (T1), it was possible to exceed $150 \%$ of primary root emergence (Figure 4 ). 
The values of production of normal seedlings showed even more that the regenerative capacity of $E$. candolleana seeds is lower than in other species of Eugenia. With the cuttings, it was not possible to obtain more than one normal seedling per seed (Figure 5), as seen in other species of the genus (Delgado et al., 2010; Teixeira and Barbedo, 2012). In addition, some forms of cutting, such as radial cutting in four parts (T2, Figure 2), were extremely harmful to seedling production (Figure 5).

In any case, the seeds exhibited regeneration of new roots, to a greater or lesser degree, even after removal of $75 \%$ of the seed reserves. This was also observed by Teixeira and Barbedo (2012), who found, moreover, that this regenerative capacity is present from immature seeds up to germinating seeds. According to these authors, this could be a strategy for preserving the species and prolonging its survival in the environment. However, this had not yet been analyzed experimentally.

Analysis of the results of regeneration of roots and seedlings when the first ones are artificially removed showed that there was significant interaction between maturity stages and types of eliminations of new roots (Figure 6) for production of new roots, but not for production of seedlings (Figure 7).

Uponeliminating the first development(EFD), germination of new roots occurred in all the stages (40\% in E1, $83 \%$ in E2, and $100 \%$ in E3 and E4, Figure 6). Upon eliminating the second development (ESD), only the first stage (E1) did not have new root emergence. Interestingly, and different from the results observed by Teixeira and Barbedo (2012), for the other maturity stages, the more immature the seed, the more efficient the regeneration of new roots $(80 \%$ in E2, 58\% in $\mathrm{E} 3$, and $33 \%$ in E4, Figure 6). However, this greater efficiency in regeneration of roots was not accompanied by seedling
$\mathbf{A}$

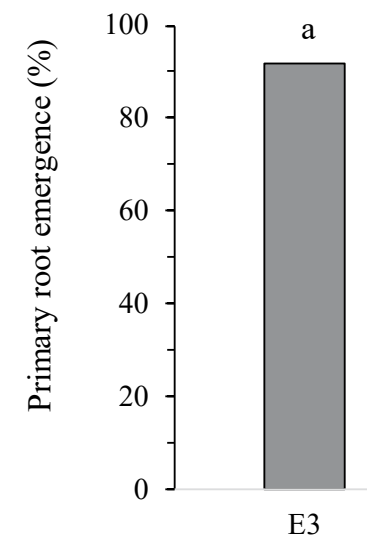

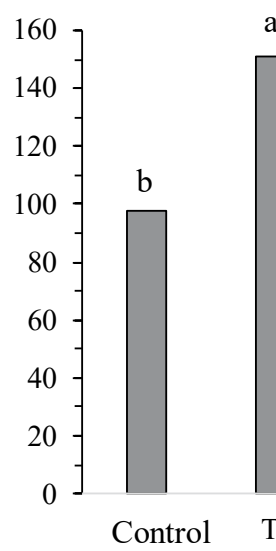

B

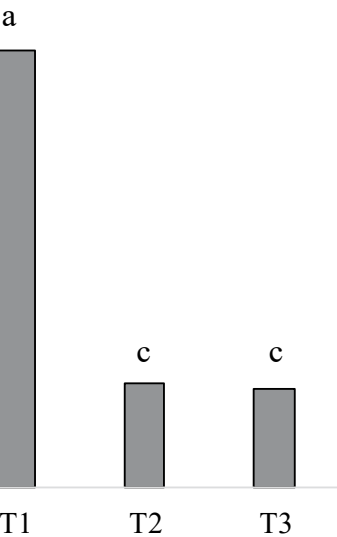

Figure 4. Primary root emergence of E. candolleana seeds in different maturity stages (A) and under different treatments of cutting (B). Mean values followed by the same letter do not differ from each other (Tukey, 5\%).

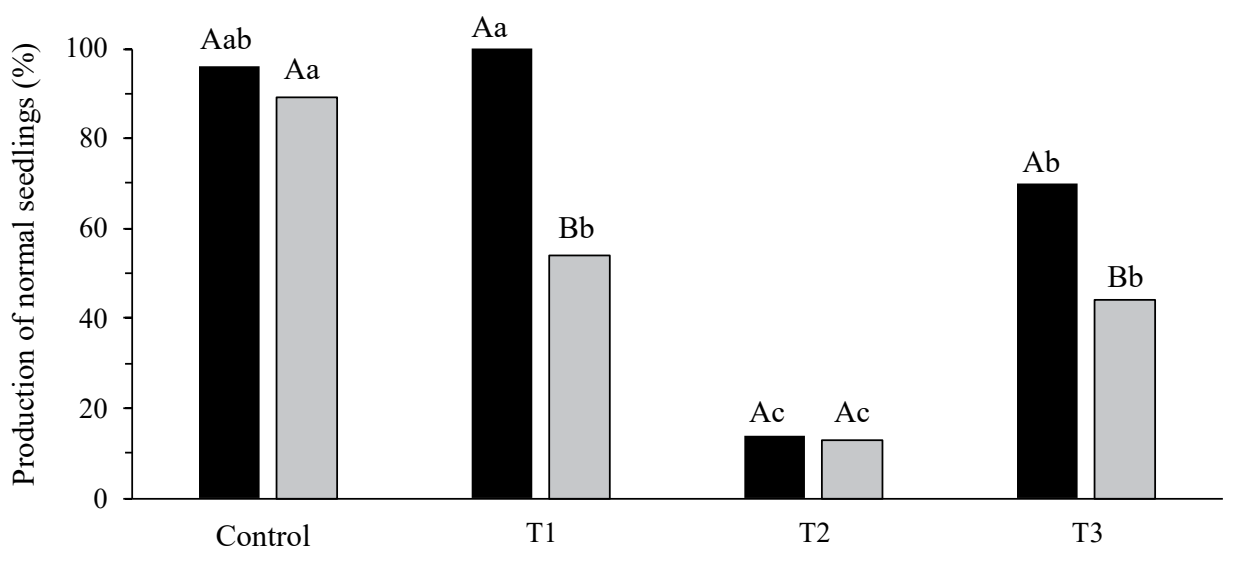

Figure 5. Production of normal seedlings from E. candolleana seeds in different maturity stages (E3, in black; E4, in gray), under different treatments of cutting (Control, T1, T2, and T3). Mean values followed by the same letter (uppercase compare maturity stages, lowercase compare cutting treatments) do not differ from each other (Tukey, 5\%). 
production (Figure 7A). Although more immature stages of Eugenia seeds already have the capacity for regenerating roots and shoots, Teixeira and Barbedo (2012) observed that their efficiency in the process is lower than that found in more mature seeds.

Greater root production in E2 may be related to its greater distance from the germination process. According to Barbedo et al. (2013), recalcitrant seeds could be understood as seeds that do not complete their maturation before being detached from the mother plant and, that way, from a certain moment in the maturation process on, in which there is this detachment, either they begin germination or they begin to deteriorate rapidly. As shown by Lamarca et al. (2013), the processes of seed maturation and fruit ripening in Eugenia pyriformis are not synchronized, just as observed in the E. candolleana seeds of this study, and the seeds in the latter stages may have been detached from the mother plant well before. Therefore, E4 could be composed of seeds in initial processes of germination, which leads to their lower regenerative capacity when the second seedling that developed is eliminated.

In general, the capacity for regeneration of new roots after elimination of the first seedling in E. candolleana seeds may be related to the large quantity of seed reserves that allow predation, and even so, the seeds continue to be capable of germination. This strategy can also be understood, from the ecological perspective, as an alternative to drying, which occurs in most orthodox seeds. This allows the species to continue in the environment by means of successive germinations from the same seed (Teixeira and Barbedo, 2012; Marcos-Filho, 2015).

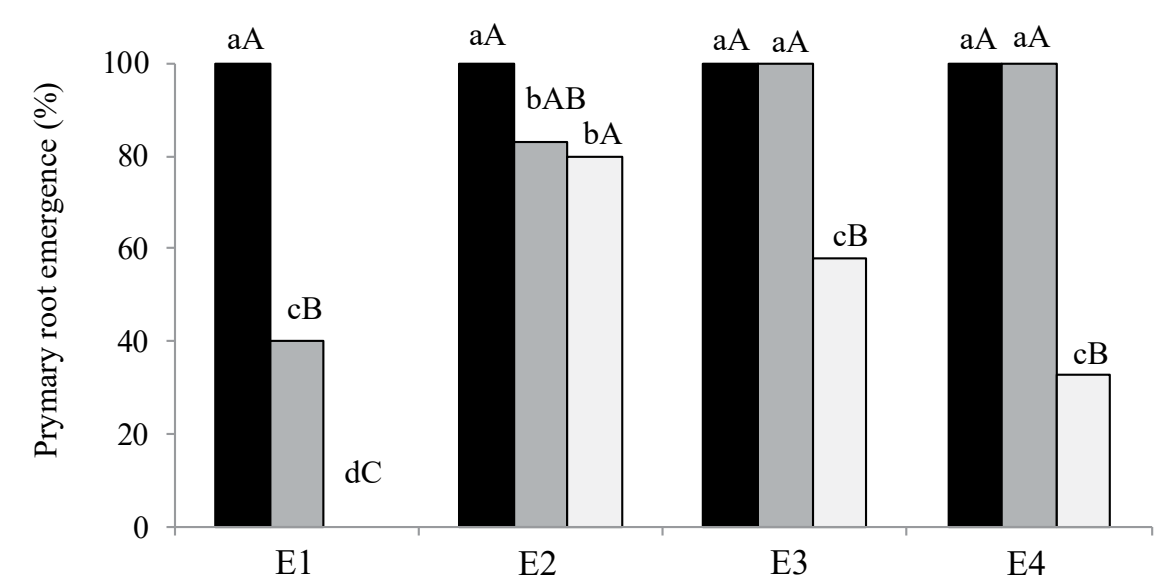

Figure 6. Primary root emergence in E. candolleana seeds in different maturity stages (E1, E2, E3, and E4) that underwent elimination of first development (columns in dark gray), elimination of second development (light gray), and without eliminations (black). Mean values followed by the same letter (lowercase comparing the different maturity stages and uppercase comparing the different types of eliminations) do not differ from each other (Tukey, $5 \%$ ).
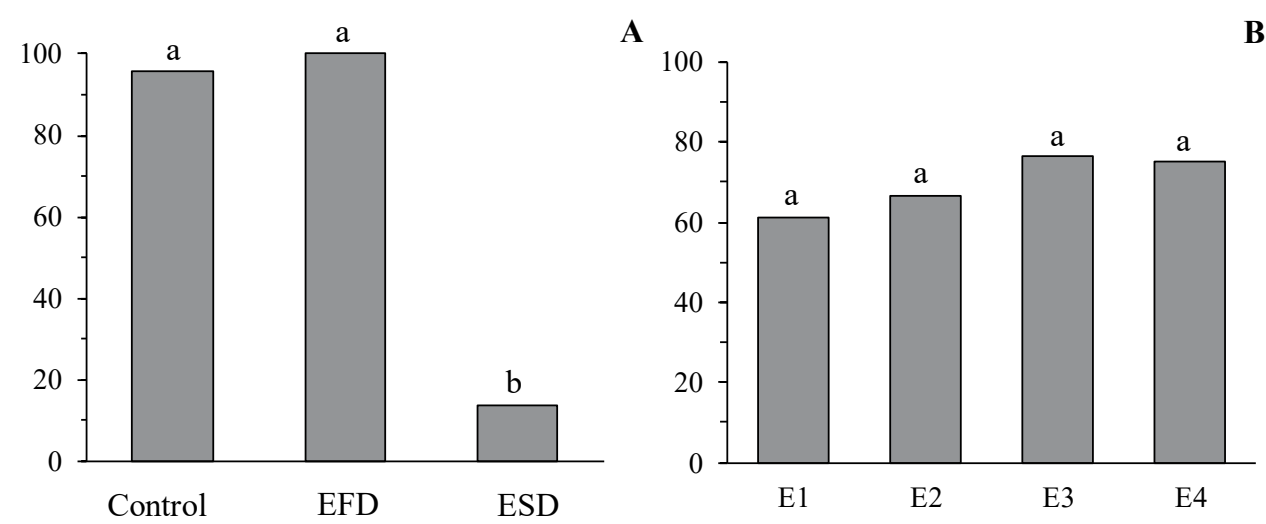

Figure 7. Production of normal seedlings (\%) in E. candolleana seeds under elimination of the first developments (A), at different maturity stages (B). Control: without eliminations; EFD: elimination of the first development; ESD: elimination of the second development. Mean values followed by the same letter do not differ from each other (Tukey, 5\%). 
Seedling development occurred in all the stages $(100 \%)$ for the seeds that were under the EFD and ESD treatments (Figure 7). In addition, after elimination of the first normal seedling, practically all the seeds were able to produce a second seedling (Figure 7). Elimination of this second seedling allowed some seeds to even produce a third seedling, although this capacity was restricted to less than $20 \%$ of the seeds (Figure 7 ).

The data on germination and development of seedlings (Figures 6 and 7) showed that the percentage of seeds able to produce seedlings was less than that of seeds able to develop only new roots. This may be related to reduction in the quantity of reserves of the cotyledons when they produce more than one seedling. The results presented here show that the regenerative capacity of seeds of Eugenia species may be related to a strategy for preservation of the species in the face of predation, both of reserve tissues and of the very roots and seedlings produced. Even when the entire seedling is eliminated, and even when this elimination is performed twice, the remaining tissue has the ability both of regenerating new roots and seedlings and of nourishing these new structures until they are able to obtain their own resources by photosynthesis.

\section{Conclusions}

The results of the experiments showed that Eugenia candolleana seeds regenerate roots and form seedlings even with reduction in their reserves, also maintaining the capacity of germinating successive times and producing seedlings, even when the first seedlings produced are lost. These characteristics may be related to adaptations of the species against predation and may also be considered an ecological strategy as a means of propagation of these seeds.

\section{Acknowledgments}

The authors thank the Conselho Nacional de Desenvolvimento Cientifico e Tecnológico (CNPq) for the Master's degree scholarship granted to the first author and to the Instituto de Botânica for permission to harvesting fruits and seeds.

\section{References}

AMADOR, T.S.; BARBEDO, C.J. Potencial de inibição da regeneração de raízes e plântulas em sementes germinantes de Eugenia pyriformis. Pesquisa Agropecuária Brasileira, v.46, p.814821, 2011. http://www.scielo.br/pdf/pab/v46n8/05.pdf
AMADOR, T.S.; BARBEDO, C.J. Germination inhibits the growth of new roots and seedlings in Eugenia unifora and Eugenia brasiliensis. Journal of Seed Science, v.37, p.241-247, 2015. http://www.scielo. br/pdf/jss/v37n3/2317-1537-jss-37-03-2317_1545v37n3150595.pdf

ANJOS, A.M.G.; FERRAZ, I.D.K. Morfologia, germinação e teor de água das sementes de araçá-boi (Eugenia stipitata ssp. sororia). Acta Amazonica, v.29, p.337-348, 1999. http://www.scielo.br/pdf/aa/ v29n3/1809-4392-aa-29-3-0337.pdf

ASOMANING, J.M.; OLYMPIO, N.S.; SACANDE, M. Desiccation sensitivity and germination of recalcitrant Garcinia kola Heckel seeds. Research Journal of Seed Science, v.4, p.15-27, 2011. http:// docsdrive.com/pdfs/academicjournals/rjss/2011/15-27.pdf

AVILA, A.L.; ARGENTA, M.S.; MUNIZ, M.F.B.; POLETO, I.; BLUME, E. Maturação fisiológica e coleta de sementes de Eugenia uniflora L. (pitanga), Santa Maria, RS. Ciência Florestal, v.19, p.61-68, 2009. https://periodicos.ufsc.br/index.php/biotemas/article/ viewFile/2175-7925.2012v25n3p11/22796

BARBEDO, C.J.; CENTENO, D.C.; RIBEIRO, R.C.L.F. Do recalcitrant seeds really exist? Hoehnea, v.40, p.583-593, 2013. http://www.scielo.br/pdf/hoehnea/v40n4/01.pdf

BRASIL. Ministério da Agricultura, Pecuária e Abastecimento. Regras para análise de sementes. Ministério da Agricultura, Pecuária e Abastecimento. Secretaria de Defesa Agropecuária. Brasília: MAPA, 2009. 395p. http://www.agricultura.gov.br/ assuntos/laboratorios/arquivos-publicacoes-laboratorio/regras-paraanalise-de-sementes.pdf/view

CALVI, G.P.; AUD, F.F.; FERRAZ, I.D.K.; PRITCHARD, H.W.; KRANER, I. Analyses of several seed viability markers in individual recalcitrant seeds of Eugenia stipitata McVaugh with totipotent germination. Plant Biology, v.19, p.6-13, 2016. https://onlinelibrary. wiley.com/doi/epdf/10.1111/plb.12466

DELGADO, L.F.; MELLO, J.I.O.; BARBEDO, C.J. Potential for regeneration and propagation from cut seeds of Eugenia (Myrtaceae) tropical tree species. Seed Science and Technology, v.38, p.624-634, 2010. https://doi.org/10.15258/sst.2010.38.3.10

DELGADO, L.F.; BARBEDO, C.J. Atividade inibidora da germinação em extratos de sementes de Eugenia uniflora L. Revista Brasileira de Sementes, v.33, p.463-471, 2011. http://www.scielo.br/ $\mathrm{pdf} / \mathrm{rbs} / \mathrm{v33n3/09.pdf}$

GAGETTI, B.L.; PIRATELLI, A.J.; PIÑA-RODRIGUES, F.C.M. Fruit color preference by birds and applications to ecological restoration. Brazilian Journal of Biology, v.76, p.955-966, 2016.http:// www.scielo.br/pdf/bjb/v76n4/1519-6984-bjb-1519-698405115.pdf

GUIMARÃES, A.G.; MELO, M.S.; BONFIM, R.R.; PASSOS, L.O.; MACHADO, S.M.F.; RIBEIRO, A.S.; SOBRAL, M.; THOMAZZI, S.M.; QUINTANS-JÚNIOR, L.J. Antinociceptive and anti-inflammatory effects of the essential oil of Eugenia candolleana DC., Myrtaceae, on mice. Revista Brasileira de Farmacognosia, v.19, p.883-887, 2009. http://www.scielo.br/pdf/rbfar/v19n4/16.pdf

JOSHI, G.; KUMAR, A.N.A.; GOWDA, B.; SRINIVASA, Y.B. Production of supernumerary plants from seed fragments in Garcinia gummi-gutta: evolutionary implications of mammalian frugivory. Current Science, v.91, p.372-376, 2006. www.iisc.ernet.in/currsci/ aug102006/372.pdf 
KERMODE,A.R. Regulatory mechanisms involved in the transition from seed development to germination. Critical Reviews in Plant Sciences, v.9, p.155-195, 1990. https://doi.org/10.1080/07352689009382286

LAMARCA, E.V.; PRATAVIERA, J.S.; BORGES, I.F.; DELGADO, L.F.; TEIXEIRA, C.C.; CAMARGO, M.B.P.; FARIA, J.M.R.; BARBEDO, C.J. Maturation of Eugenia pyriformis seeds under different hydric and thermal conditions. Anais da Academia Brasileira de Ciências, v.85, p.223-233, 2013. http:/www.scielo.br/ pdf/aabc/v85n1/0001-3765-aabc-85-01-223.pdf

LENARDÃO, E.J.; SAVEGNAGO, L.; JACOB, R.G.; VICTORIA, F.N.; MARTINEZ, D.M. Antinociceptive effect of essential oils and their constituents: an update review. Journal of the Brazilian Chemical Society, v.27, p.435-474, 2016. http://www.scielo.br/pdf/ jbchs/v27n3/0103-5053-jbchs-27-03-0435.pdf

LORENZI, H. Árvores brasileiras: manual de identificação e cultivo de plantas arbóreas nativas do Brasil. v.3. Nova Odessa: Instituto Plantarum, 2009.

MALIK, S.K.; CHAUDHURY, R.; KALIA, R.K. Rapid in vitro multiplication and conservation of Garcinia indica: A tropical medicinal tree species. Scientia Horticulturea, v.106, p.539-553, 2005. https://doi.org/10.1016/j.scienta.2005.05.002

MARCOS-FILHO, J. Fisiologia de sementes de plantas cultivadas. Londrina: ABRATES, 2015. 660p.

NAKAMURA, M.J.; MONTEIRO, S.S.; BIZARRI, C.H.B.; SIANI, A.C.; RAMOS, M.F.S. Essential oils of four Myrtaceae species from the Brazilian southeast. Biochemical Systematics and Ecology, v.38, p.1170-1175, 2010. https://doi.org/10.1016/j.bse.2010.11.003

NASCIMENTO, W.M.O.; TOMÉ, A.T.; CARVALHO, J.E.U.; MÜLLER, C.F. Comportamento fisiológico de sementes de mangostão (Garcinia mangostana L.) submetidas a diferentes períodos de fermentação da polpa. Revista Brasileira de Fruticultura, v.23, p.735-737, 2001. http://www.scielo.br/pdf/rbf/v23n3/8062.pdf

NEVES, I.A.; REZENDE, S.R.F.; KIRK, J.M.; PONTES, E.G.; CARVALHO, M.G. Composition and larvicidal activity of essential oil of Eugenia candolleana DC. (Myrtaceae) against Aedes aegypti. Revista Virtual de Química, v.9, p.2305-2315, 2017. http://rvq.sbq. org.br/imagebank/pdf/v9n6a12.pdf
OFORI, D.A.; ASOMANING, J.M.; PEPRAH, T.; AGYEMAN, V.K.; ANJARWALLA, P.; TCHOUNDJEU, Z.; MOWO, J.G.; JAMNADASS, R. Addressing constraints in propagation of Allanblackia spp. through seed sectioning and air layering. Journal of Experimental Biology and Agricultural Sciences, v.3, p.89-96, 2015. http://www. jebas.org/00300120022015/Ofori\%20et\%20al\%20JEBAS.pdf

ORO, P.; SCHULZ, D.G.; VOLKWEIS, C.R.; BANDEIRA, K.B.; MALAVASI, U.C.; MALAVASI, M.M. Maturação fisiológica de sementes de Eugenia pyriformis Cambess e Eugenia involucrata DC. Biotemas, v.25, p.11-18, 2012. https://doi.org/10.5007/21757925.2012v25n3p11

PRATAVIERA, J.S.; LAMARCA, E.V.; TEIXEIRA, C.C.; BARBEDO, C.J. The germination success of the cut seeds of Eugenia pyriformis depends on their size and origin. Journal of Seed Science, v.37, p.47-54, 2015. http://www.scielo.br/pdf/jss/v37n1/2317-1537jss-37-01-00047.pdf

SANTANA, D.G.; RANAL, M.A. Análise da germinação: um enfoque estatístico. Brasília: Editora UnB, 2004.

SILVA, C.V.; BILIA, D.A.C.; BARBEDO, C.J. Fracionamento e germinação de sementes de Eugenia. Revista Brasileira de Sementes, v.27, p.86-92, 2005. http://www.scielo.br/pdf/rbs/v27n1/25185.pdf

TAIZ, L.; ZEIGER, E. Fisiologia Vegetal. 3.ed. Porto Alegre: Artmed, 2004.

TEIXEIRA, C.C.; BARBEDO, C.J. The development of seedlings from fragments of monoembryonic seeds as an important survival strategy for Eugenia (Myrtaceae) tree species. Trees, Structure and Function, v.26, p.1069-1077, 2012. http://dx.doi.org/10.1007/ s00468-011-0648-5 